\title{
Consumer Response Analysis to the Electronic Brands
}

\author{
Helena Nobre \\ Carlos Melo Brito \\ Paulo de Lencastre
}

\begin{abstract}
This paper studies the consumer response to the electronic brands-i.e., brands commercialized on the Internet. The results of the study suggested that, although the specific ebranding practices might allow building awareness in a short period of time, the profitability of on-line brands is likely to rely on the same factors as the traditional brand: time and financial efforts. Finally, the study also suggested that in the future, with the broadband and the consequent media convergence, marketers could not regard to an on-line brand as the opposite of a physical brand. Rather, brands have to be managed in a comprehensive way, taking into account all alternatives based not only on the kind of product/service but also on the desired positioning. [Article copies available for a fee from The Haworth Document Delivery Service: 1-800-HAWORTH. E-mail address: <docdelivery@haworthpress.com> Website: <http://www.HaworthPress. com> () 2004 by The Haworth Press, Inc. All rights reserved.]
\end{abstract}

KEYWORDS. Ecommerce, branding, on-line brands, relationship marketing, consumer behavior

Helena Nobre is affiliated with the Instituto Politécnico de Viana do Castelo, Escola Superior de Ciências Empresariais, Av. Miguel Dantas 4930-678 Valenceca, Portugal (E-mail: helenamnobre@hotmail.com).

Carlos Melo Brito is affiliated with the University of Porto, Portugal, Rua Dr. Roberto Frias, 4200 Porto, Portugal (E-mail: cbrito@fep.up.pt).

Paulo de Lencastre is affiliated with Catholic University, Portugal, Rua Diogo Botelho, 1327, 4169-005 Porto, Portugal (E-mail: plencastre@ porto.ucp.pt).

Journal of Transnational Management, Vol. 10(1) 2004 Available online at http://www.haworthpress.com/web/JTRAN

(C) 2004 by The Haworth Press, Inc. All rights reserved. doi:10.1300/J482v10n01_05 
Branding has become a fundamental issue for the implementation of successful on-line commercial strategies and, consequently, for the survival of the electronic commerce. The importance of brands to the electronic commerce is related to three factors: customer retention, identification and localization of brands, and the offer of an added value both to companies and customers. Branding has evolved over the past few decades, accompanying the evolution of marketing. Since the '50s, segmentation has become a good practice in marketing. This demands a good knowledge of consumer habits, in order to group them according to criteria previously defined. Later, from the '80s on, loyalty, customer retention and lifetime value became common metrics for branding.

However, with the growing importance of ebusiness and, in particular, on-line marketing, the buyer-seller relationship tends to assume an important dimension in branding (Moon \& Millison, 2000). This shift is the result of the need to find new forms of responding to the demand of the market through the relationship marketing and the one-to-one marketing (Brito, 1998). At the same time, these are the result of the development of information technologies (IT) that have given to companies the electronic means to interact directly with customers (Reis, 2000).

The creation and maintenance of traditional brands implied, in most cases, strong and continued investments, which tends to result in a slow process. But, as Diorio (2002) put it, the Internet shows that time and economic factors can be less important in the building of brand awareness in an ecommerce context. In part, this results from the fact that the Internet offers low entry barriers, namely the technical ones (Carpenter, 2000). On the other hand, given that this is still a recent market, it is possible that the quickness in building awareness of some on-line brands is related to the "first mover advantage" factor.

Although the emarketplace tends to be quicker and less predictable than the off-line market (at least so far), there is a tendency of market convergence. In this sense, the physical and virtual market are merging in just one space which leads to the use of the most effective channels in the establishment and defense of a brand (Rayport \& Jaworski, 2002). This means that in the near future differences between physical and virtual brands are likely to disappear.

In short, ebranding represents a new major research area in ecommerce. This is a relatively unexplored area where questions remain without answers. Indeed, with the Internet, it was never so easy to build a recognized brand in the short term like now. But, on the other hand, it was never so ephemeral and volatile. 
This paper attempts to understand whether virtual branding needs a different approach than physical branding. On the other hand, given that the Internet brought deep changes in terms of consumers' behavior and in the way brands relate to them, this resulted in new challenges for marketers. This raised two specific questions that have also assisted this study: Did the Internet and the consequent media convergence introduce any change for traditional branding? What does the Internet mean exactly to any brand?

\section{FRAMEWORK FOR ANALYSIS}

To address those research questions, a framework was developed for guiding the on-line brands case studies analysis of this research, in order to verify (in an exploratory way) the hypotheses of study.

Given that the study of on-line brands demands both a deep understanding of the environment where they operate, and their theoretical support, it is necessary to offer a general picture of the state of art in terms of two research fields: the electronic commerce and the classical brand theory.

Firstly, there is the necessity of an ebranding practices referential system, in order to compare each case studied. The set of best ebranding practices proposed by Carpenter (2000) was considered as a referential system. Such a system includes the specific practices to the physical brands extended to the on-line market. However, given that brands may not present on-line affinity, it became fundamental to inquire about the pertinence of an electronic brand strategy. In this sense, the scorecard developed by Diorio (2002) is a useful tool.

To analyze a brand is fundamental to understanding its identity structure as well as the elements of its identity mix, marketing mix and public mix (Lencastre, 1999). The way a brand is perceived by the public influences its own identity. In this way, it is very important to know how to characterize its image mix, which, in turn, requires the identification of the level of awareness and the associations to the brand.

Brands have become an inherent framework of any marketing strategy. In particular, the establishment of an ebrand strategy should be on-line with the central aspects of the marketing strategy adopted. In this sense, the framework for analysis was built on the basis of two models: 
The Electronic Commerce Consumer Behavior Model developed by Turban et al. (2000), since the consumer's behavior is a determinant factor to the implementation of a brand strategy.

The Relationship Marketing Model developed by Turban et al. (2000), since the techniques of relationship marketing make all sense in a brand strategy because their capacity of improving the satisfaction and loyalty levels.

Moreover, three other aspects were also taken in account:

CLV (Customer Lifetime Value) as a criteria to measure the customers' profitability.

One-to-One Marketing Strategies ranging from customization of products, services, delivering, to other customer's interactions, which are usually supported by a CRM (Customer Relationship Management) framework, and represents an important tool for the customer fidelization.

Loyalty Programs as worth tools for the customer retention and the increasing of customer's profitability.

After selecting the essential elements of the framework for analysis, it became necessary to integrate them. In order to obtain a coherent tool, which allowed for the evaluation of an on-line brand strategy from a holistic perspective. Being the consumer behavior determinant for the choice of a brand strategy, in particular, the consumer behavior in the on-line market emerges as a central point to an electronic brand strategy. Thus, the Electronic Commerce Consumer Behavior Model (Turban et al., 2000) was assumed as integrator element of the issues that involve the study of on-line brand strategies. In fact, the model showed in Figure 1 integrates the selected electronic commerce elements, and allows systematizing and relating the information, establishing in parallel, the bridge to the brand theory.

Also, actions of relationship and one-to-one marketing that add value to the customer appeared as a stimulus to the purchase process. Those actions try to influence a favorable decision to the brand in a moment, but also to make it permanent through the customer retention. For that, the systems of vendor's responsibility, such as fidelization programs, customization strategies, logistics, technical or customer service of excellence are likely to be 
FIGURE 1. EC Consumer Behavior Model as Integrator Element of the Three Theoretical Themes

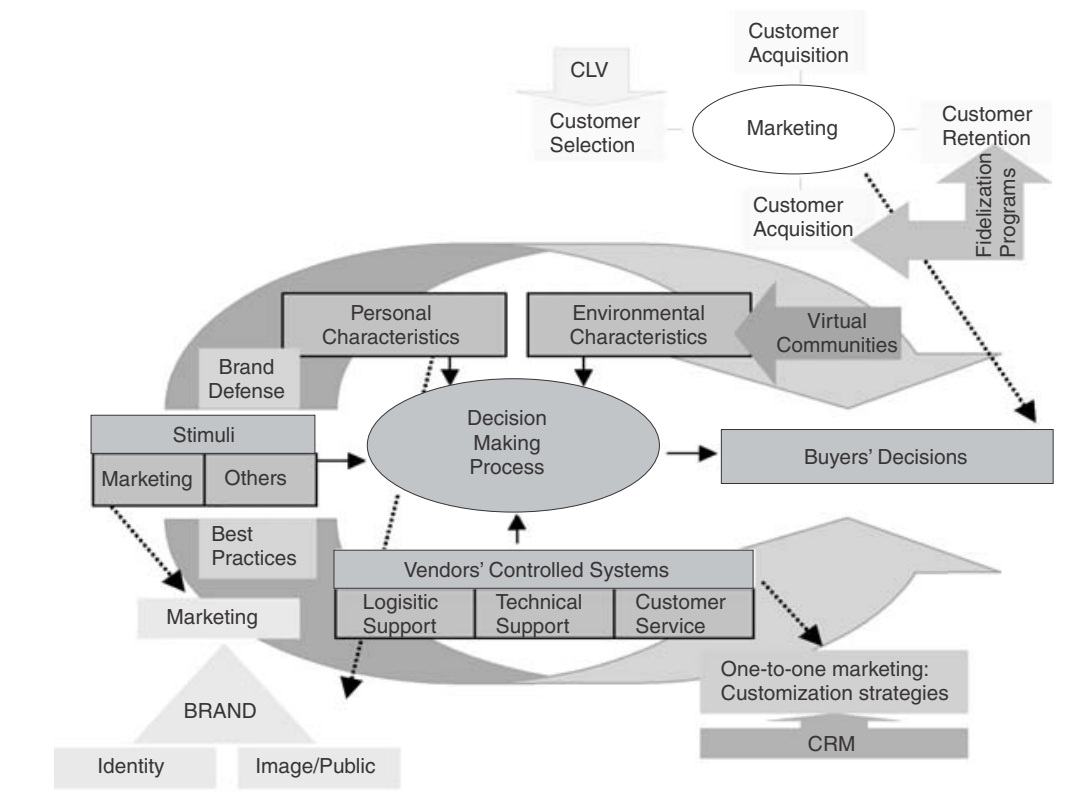

Source: own systematization.

important tools. On the other hand, the establishment of a relationship marketing strategy needs to segment the customers in terms of delivered value to the company, where the LCV emerges as an important notion. Also, the existence of a CRM assumes an essential role in an efficient relationship strategy, mainly when it takes the form of one-to-one marketing.

Side by side to the traditional marketing actions, ebranding practices constitute an important tool for this process, since they have an impact at the level of both brand symbolic character and functionality. Also, the issues about defense of brand in the on-line market must be mentioned in this aim, namely the virtual communities as an environmental characteristic, which act like stimuli for the purchasing decision process.

In short, the analysis of on-line brands might take into account two facts. Firstly, to know how to characterize a brand, how to evaluate its electronic commerce affinity and its ebranding specific actions. Secondly, to know how to characterize its emarketing strategy, that is the 
company's posture towards electronic commerce in terms of technical and logistic support, customer service, and actions of relationship and one-to-one marketing.

The depuration of the relations that Figure 1 establishes among the selected theoretical elements results in a framework for analysis that tries to inquire about brand strategy toward electronic commerce (Figure 2). Taking into account the hypotheses of the study, this tool uses as input one of the following brand types: physical brand and pure digital brand.

The first step consists of the brand characterization and its emarketing strategy. Then, this information passes through the scorecard that gives a "grade" according to the brand ability to on-line market. The framework provides two final situations. If the brand shows on-line affinity, the framework will provide a referential of good ebranding practices. If the brand does not show on-line affinity, the framework will suggest that the brand should

FIGURE 2. Framework for Analysis for On-Line Brands

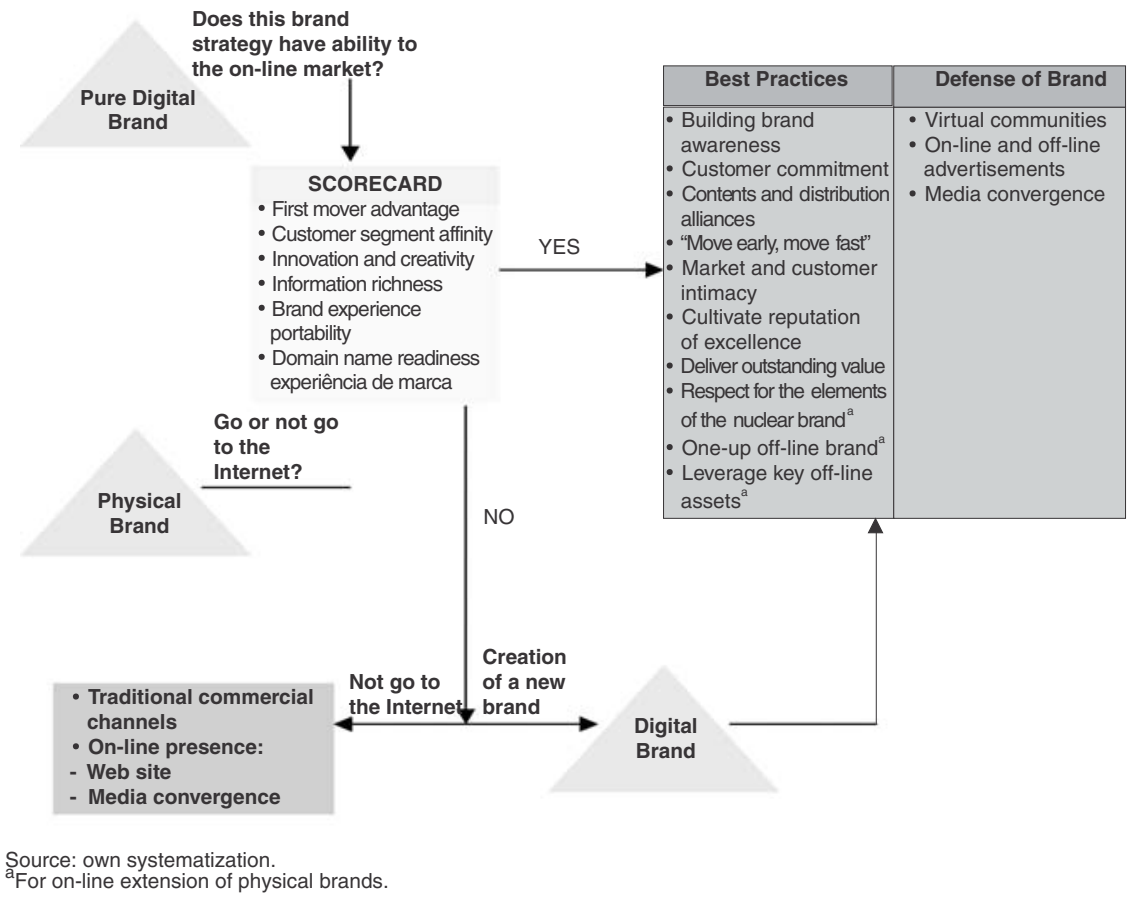


choose the physical channels, however maintaining an on-line presence through an institutional Web site, and a general concern with the media convergence.

\section{METHODOLOGY}

The research strategy was chosen, fundamentally, according to the fact that ebranding is an area of knowledge which presents characteristics that Yin (1994) considers that could be well studied by exploratory case studies. In fact, it is a new field of study that presents neither a well-established and accepted conceptual framework, nor relevant hypotheses of studying. Thus, an exploratory approach was chosen, based on qualitative methods through a multiple-case study analysis.

The use of case studies is more adequate when a "how" or "why" question is being asked about a contemporary set of events over which the investigator has little or no control (Yin, 1994, p. 9). However, the author refers that use of cases is also adequate for studies where exploratory questions are posed with the goal of developing hypotheses and propositions for further test.

In this study, the main question of research has an exploratory purpose-does a virtual brand need a different approach than physical brand? If so, in what aspects? Thus, the main objective is to formulate hypotheses of study about the on-line brand management. However, it was hypothesized that "the customer response to electronic brands is different from the traditional brands." Therefore, this study has also an explanatory character, which is evident in the theoretical framework for analysis.

On the other hand, Yin recommends the study of cases when "the boundaries between phenomenon and context are not clearly evident" (1994, p. 13). In fact, in this study it was difficult to separate the ebranding issue from its context: ecommerce and traditional branding.

The development of the empirical study encompassed the following steps:

The individual analysis of each case was done on the basis of theoretical framework (see Figure 2).

The patterns obtained and the hypotheses raised were then compared across three cases through the theoretical framework, according to a replication logic. ${ }^{1}$ 
The results of the cross-cases analysis delivered the study's conclusions and, consequently, the answer to the research questions.

So, on the one hand, the framework for analysis offers a logic struc-

ture, based on the hypotheses of study, which allows analyzing a brand's strategy toward the electronic commerce. On the other, such a framework represents a descriptive tool for systematizing and organizing the information, which permits the cases description and analysis according to a coherent pattern, with the goal of establishing consistent comparisons inside the multi-case study. In this sense, the cases were treated according to the dimensions of analysis derived from the theoretical framework.

The study relied on three brands:

- Timberland.

- Boston Coffee Cake.

- Napster.

These brands were chosen in order to represent three different business areas. Timberland is a physical brand with international recognition. It was later extended to the on-line market, which represents the mass marketing business model. Boston Coffee Cake is a physical brand, which uses the Internet as an alternative channel, oriented to a market niche. The last one-Napster-was a digital company with a oneto-one marketing approach. This allowed generalizing the results of this study to other similar brands.

\section{THE EMPIRICAL STUDY}

\section{Multi-Case Study Description}

While Timberland and Boston Coffee Cake are crossovermarketers, Napster is a typical case of a start-up. However, it stopped the activity and was acquired by an important European media corporation-the German Bertelsmann.

Yet, as stated before, the individual cases represent three different business models: mass marketing through Timberland, niche marketing through Boston Coffee Cake, and one-to-one marketing through Napster (see Table 1). Napster did not find yet a business model, because it was not rewarded for the benefit that delivered to its users. 
However, its experience and P2P technology might sustain, in the future, a profitable one-to-one strategy.

Timberland and Napster are widely recognized brands. However, while the first one is a large multinational corporation, the second is just a small company that appeared during the New Economy boom. Timberland is internationally recognized through its store network all over the world. Napster is the result of an innovative idea of P2P music file sharing, which, through the viral Internet abilities, gained a huge on-line audience in only one year. By contrast, Timberland had to run a long way until arriving the level of awareness that it has today. While Timberland has access only to the international market through its store network (and now, also through its Web site for the North American market), Napster had access to the global market-i.e., every place in any time.

Timberland's ecommerce challenge has the main goal to reinforce the physical brand-but, with a very careful posture that does not allow large and risked investments. The on-line brand did not present significant results yet. It relies on very loyal customers that look for products that they already know.

Boston Coffee Cake refers both a small familiar manufactory and the product that it produces and commercializes. The brand has a low differentiation level, and the product presents small distinctive ability. The brand is oriented to a niche market, presenting a high level of quality and corresponding prices.

Although it is mainly a B2B case, since the beginning Boston Coffee Cake sells its products to the final segment through paper catalogs. Subsequently, the company has extended this direct marketing experience

TABLE 1. General Characterization of Multi-Case Study

\begin{tabular}{|c|c|c|c|}
\hline & Timberland & Boston Coffee Cake & Napster \\
\hline Business model & Mass marketing & Niche marketing & One-to-one marketing \\
\hline Activity & Manufacturer & Manufacturer & Electronic distributor \\
\hline Kind of product offered & Tangible, durable & Tangible, perishable & Intangible, durable \\
\hline Market & International & $\begin{array}{l}\text { USA and Europe (in very } \\
\text { small scale) }\end{array}$ & Global \\
\hline Channels & Physical stores and Internet & $\begin{array}{l}\text { Physical stores, paper } \\
\text { catalog and Internet }\end{array}$ & Internet \\
\hline Customers/Users & $\begin{array}{l}\text { Final consumers and } \\
\text { intermediates }\end{array}$ & $\begin{array}{l}\text { Intermediates and final } \\
\text { consumers }\end{array}$ & Web users \\
\hline Beginning of activity & 1973 & 1993 & 1999 \\
\hline Number of employees & 5,400 & 40 & 8 \\
\hline
\end{tabular}


to the on-line channel. However, these two channels represent a small marketing share. Through the Internet, the brand started to commercialize the products in Europe for the first time, although such still represents a very small business.

The following points present the detailed analysis of each case study.

\section{Results Analysis}

The first remark that comes up by comparing these three cases (see Table 2) is the different ways of building awareness: two traditional brands that present long and huge efforts of communication, and a pure virtual player that built a recognized brand in about one year. Timberland did not have an easy on-line entering, what obliged it to make some specific ebranding investments. In opposite, Napster created a notorious brand in a short period of time through a viral marketing strategy.

Napster failed as a business model and lost a huge amount of money for sustaining its on-line community, because a free delivered product was the reason of the strong viral marketing, and it was not able to make that audience profitable (for instance, by captivating advertisement). Timberland and Boston Coffee Cake present strategies that are very rigorous in terms of costs. However, despite the failure, Napster, through the brand associations that it got, established a fruitful alliance with Bertelsmann that might make the brand profitable.

This leads to an important conclusion: the customer response to electronic brands is not so different from traditional brands (in opposition to the main hypothesis of this study). In fact, the slow and hard adherence to the on-line versions of the two studied crossovermarketers is usual for traditional marketing, where building a brand takes a long time and large marketing investments. Furthermore, certain initiatives of product extension or other innovations in terms of brand associations did not prove to be always successful, even to well-established brands. So, in these two cases, the on-line approach reflects an innovation in terms of commercial channel, rather the creation of a different brand. In addiction, if there is not customer segment affinity with this new channel, or the brand cannot be easily transferable to on-line, it will be expected that the ebrand establishment becomes a slow process.

Indeed, from the scorecard application, which constitutes the first step of the framework for analysis (see comparing analysis-Table 3), it was concluded that Timberland does not present a relevant on-line affinity. So, the only aspect that could encourage this on-line transference 


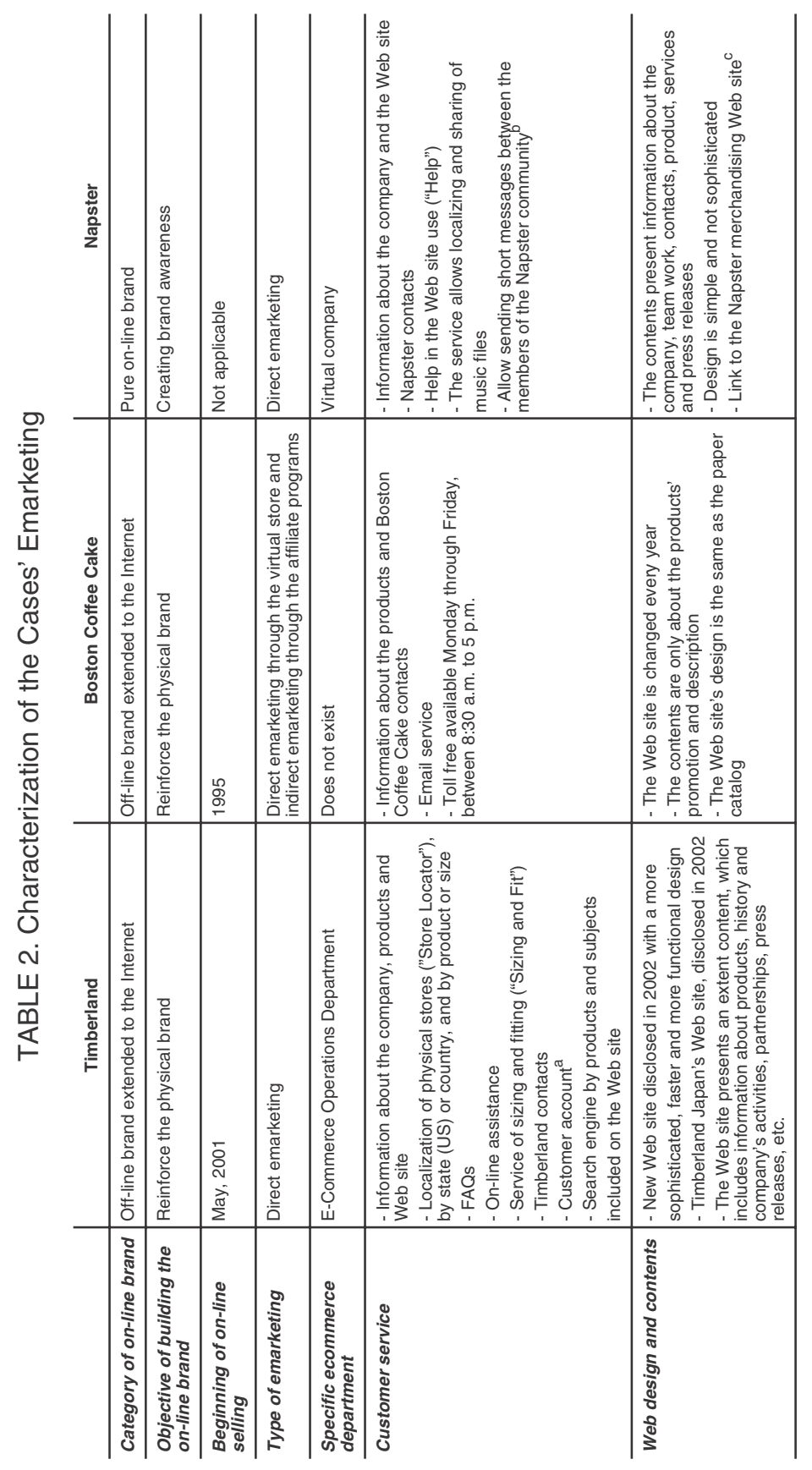




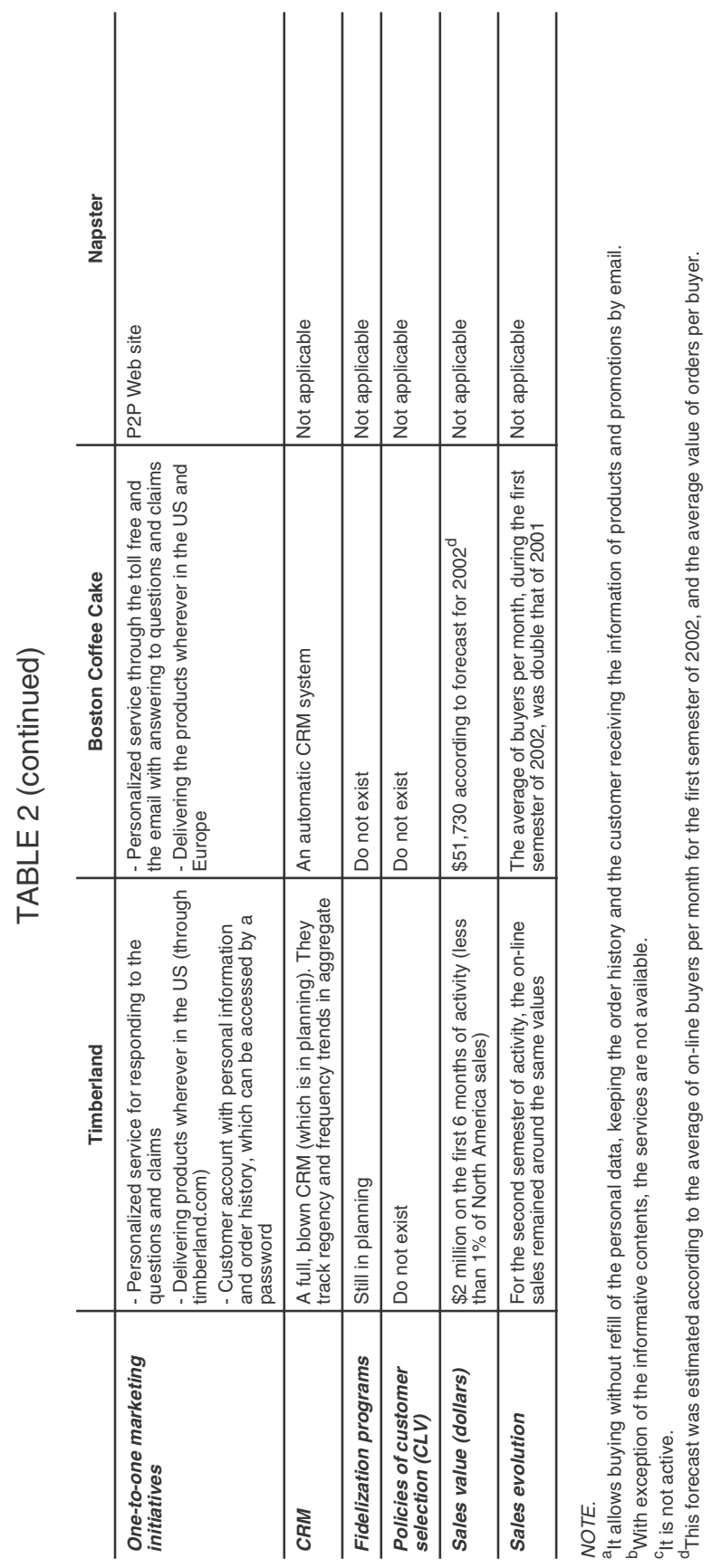




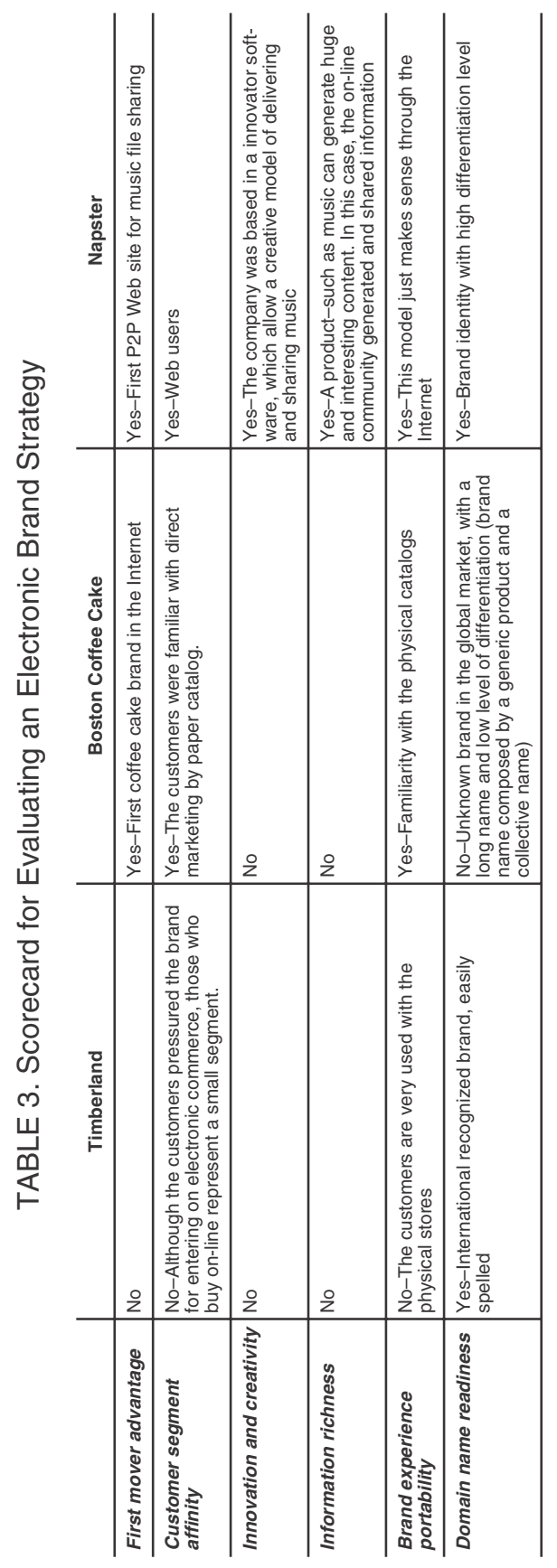


was the brand's name, which is internationally recognized and has strong associations.

The Boston Coffee Cake on-line transference was easier, but almost restricted to a small segment which corresponds to the paper catalog customers and, evidently, used with direct marketing. However, the brand shows a little known identity (namely in its main market, North America) and with a weak capacity of differentiation.

The low on-line affinity of Timberland's customers (which are familiar with the physical stores) is the reason for the last Web investments of this brand. Indeed, the company is aware that the survival of the electronic brand relies on a new customer segment. Such might imply the need of either building a different brand for operating on-line, or including new elements in the ebrand strategy, which has been relegated.

In fact, Table 4 (which establishes a comparative analysis of ebranding practices between the three brands) shows that Timberland presents two gaps at the level of "forge contents and distribution alliances" and "move early, move fast." Thus, Timberland can only invest in the first practice, which might favor the building of a virtual community through the access to contents of interest. A virtual community along the use of more interactive advertising that converges different media means (issues that constitute the third step of the theoretical framework) could favor the acquisition, for instance, of a younger segment more used to electronic commerce.

The power of viral marketing on the Internet, which is illustrated by the case of Napster, brings a new light on the customer response to brands. But, how can a product brand generate an effective viral marketing? Carpenter (2000) refers that such is possible through the building of a virtual community, the delivering of important contents and outstanding value to the customers. However, such is not always compatible with the type of offered product. For instance, what kind of content could Boston Coffee Cake deliver? The best that Boston Coffee Cake can offer through the Internet is more convenience.

On the other hand, the successful former Napster's community was the result of delivering a free product with commercial value. This leads to another conclusion: maybe the on-line users are more interested in getting free service and value while it can be possible. This means that the future of the Internet as profitable distribution channel of products and services might depend on the implementation of rules that control the information delivered. 


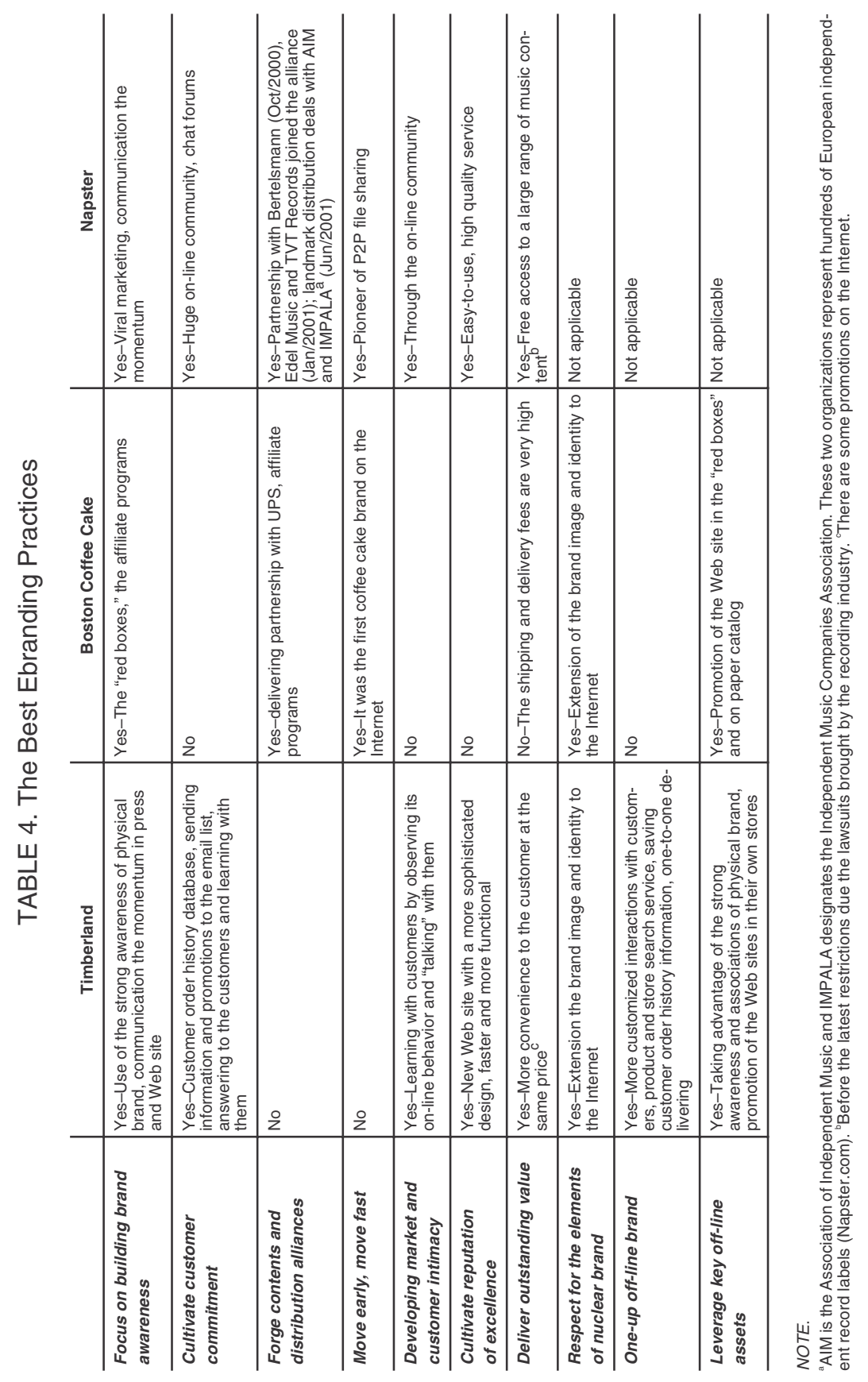




\section{CONCLUSIONS}

The main contribution of the research project described in this paper can be classified in four levels:

\section{Virtual Brands Approach}

The main question of the research was:

Does a virtual brand need a different approach than physical brand? If so, in what aspects?

To get an answer to this question, it is necessary to know the kind of brand and its marketing tools. In fact, a brand that is sold just on the Internet must have a different communication strategy from a traditional brand sold in visible physical stores. So, the brand must become "visible" whether by viral marketing, off-line advertisement, or physical assets. Therefore, it is essential to manage the communication efforts according to the characteristics and habits of the target public. But, the basic issues of customer satisfaction and delivering value to the consumer remain important factors in determining the brand success, both in the traditional market and in the on-line market.

\section{On-Line Presence}

The second research hypothesis assumed that the electronic commerce is not for all brands, but all of them should make an on-line presence. Timberland is a good example of a low on-line affinity brand that was forced to go to the Web. Regarding this, the scorecard revealed to be an important tool for measuring the on-line transference ability.

\section{The Best Practices for Brands}

In what concerns the best ebranding practices, the real importance that they can assume relies fundamentally on the type of brand, product and marketing strategy. Indeed, those practices revealed themselves as effective tools of building brand visibility, but such does not necessarily mean brand profitability. In fact, the case of Boston Coffee Cake, where the Internet appeared as a complementary commercial channel of the physical brand strategy, revealed itself as a contrasting example of that theory.

Consequently, the third hypothesis-in the near future, differences between physical and virtual brand might be limited to the level of the 
marketing mix's actions and tools-became obvious after the analysis of the three cases.

\section{The Internet Impact}

The second level of specific research questions were:

Did the Internet and the consequent media convergence bring changes for traditional branding? What does the Internet mean exactly to any brand?

This deserves a positive answer and an explanation of its meaning. Indeed, the media convergence and the Internet means new capabilities for the traditional marketing. In this sense, the classical branding must evolve and use new approaches. Namely, it seems evident that every brand tends to have an on-line presence. So, if, on the one hand, the traditional branding theory maintains its relevance, on the other, a brand can not forget the new means and channels that the development of technology brought.

This study, representing an exploratory approach, had as one of the main objectives to provide suggestions for further research. Thus, the new ways that traditional marketing must consider in a brand strategy (regarding both on-line and off-line channels) emerges presently like an important research field. The challenge of making a brand profitable through the Internet revealed itself as an interesting study theme.

Also, it would be interesting to obtain other information sources besides those that were used. That might allow for a better confrontation and validation of the data collected. Namely, Napster's Web site (as it was) does not exist anymore, so it was not possible to make neither recent direct observation, nor contact its managers.

Finally, the validation of the framework for analysis emerges as a question that deserves more attention. Such implies to verify, in a more effective way, both the brand classic theory relevance for electronic commerce, and the practical ebranding theory-i.e., the scorecard of Diorio (2002) and the best ebranding practices proposed by Carpenter (2000). In this way, it would be also interesting to test the hypotheses in a larger base of generalization, that is with more, different and contrasting cases.

\section{NOTE}

1. According to Hersen and Barlow (1976), the replication logic for multi-case studies is analogous to the same that underlies the use of multiple experiments. Thus, the replication takes place when similar results for different individual cases appear. 


\section{REFERENCES}

Brito, C. M. (1998). A Insustentável Leveza do Marketing (working paper, no. 81) [Electronic version]. Porto, Portugal: Faculdade de Economia do Porto.

Carpenter, P. (2000). eBrands: Building an Internet Business at Breakneck Speed. Boston: Harvard Business School Press.

Diorio, S. (2002). How technology changes branding: Tthe changing rules of awareness, identity and loyalty in the 21 st century [Electronic version]. In S. Diorio (Ed.), Beyond e: 12 Ways Technology is Transforming Sales and Marketing Strategy. McGraw-Hill.

Hersen, M., \& Barlow, D. H. (1976). Single-Case Experimental Designs: Strategies for Studying Behavior. New York: Pergamon.

Lencastre, P. (1999). A Marca: O Sinal, a Missão e a Imagem. Revista Portuguesa de Marketing, 8, 105-119.

Moon, M., \& Millison, D. (2000). Firebrands-Building Brand Loyalty in the Internet Age. Berkeley, CA: MacGraw-Hill.

Napster (n.d.). Web site of Napster. Available from www.napster.com.

Rayport, J. F., \& Jaworski, B. J. (2002). Cases in e-Commerce. New York: McGrawHill/Irwin.

Reis, J. L. (2000). O Marketing Personalizado e as Tecnologias de Informação. Matosinhos, Portugal: Edições Centro Atlântico.

Turban, E., Lee, J., King, D., \& Chung, H. M. (2000). Electronic Commerce: A Managerial Perspective. Upper Saddle River, NJ: Prentice Hall.

Yin, R. (1994). Case Study Research: Design and Methods (2nd ed.). Thousand Oaks, CA: Sage Publications.

RECEIVED: November 2003

REVISED: January 2004

ACCEPTED: March 2004 